\title{
EVALUATION OF PRETERM INFANTS DURING THE FIRST OFFERING OF THE MATERNAL BREASTFEEDING IN A NEONATAL INTENSIVE CARE UNIT
}

\author{
Avaliação de recém-nascidos prematuros durante \\ a primeira oferta de seio materno em uma uti neonatal
}

Patrícia Keitel da Silva (1), Sheila Tamanini de Almeida ${ }^{(2)}$

\begin{abstract}
Purpose: to evaluate newborn prematures during the first offering of maternal breast in a Neonatal Intensive Care Unit. Methods: 15 mother-newborn dyads were assessed during the first offering of maternal breast in the Neonatal Intensive Care Unit in Maternity Mario Totta in the Hospital Santa Clara da Irmandade Santa Casa de Misericórdia de Porto Alegre. The collection occurred in three parts with each dyad: 1st) Inquiry newborn records and filling out a form. 2nd) Application a structured questionnaire to mothers. 3rd) Assessment the first offer of maternal breast applying the Speech Therapy Evaluation Form feedings. Results: $46.7 \%$ of newborn had prematurity as the sole reason for admission, $60 \%$ were already in speech therapy before initiating breastfeeding. Mean maternal age was $29.27+/-8.058$ years and $73.3 \%$ had a stable relationship with the father of the newborn. It was found that the higher the corrected gestational age of newborns, the best conditions for making the handle and milking breast, and final classification of breastfeeding. More days of life the newborn had the best handle in the maternal breast. Conclusion: prematurity was the main factor against breastfeeding, however, the positive characteristics of the mothers, a like educational level, marital status and previous experience in breastfeeding and the early onset of therapeutic sessions in most prematures may have provided good results in the first offering of the maternal breast.
\end{abstract}

KEYWORDS: Breast Feeding; Infant, Premature; Intensive Care Units, Neonatal

\section{INTRODUCTION}

Breastfeeding is the most natural and safe way to feed a newborn premature. Breastfeeding has a unique combination of proteins, lipids, carbohydrates, minerals, vitamins, enzymes and living cells, and the unquestionable nutritional benefit, immunological, physiological and economical. The recommendation of breastfeeding for preterm infants has been advocated based on the immunological properties, its role in gastrointestinal maturation, the

(1) Programa de Residência Multiprofissional Integrada em Saúde com Ênfase em Intensivismo, UFCSPA/ISCMPA, Porto Alegre, Rio Grande do Sul, Brasil.

(2) Curso de Fonoaudiologia, UFCSPA, Porto Alegre, Rio Grande do Sul, Brasil.

Conflict of interest: non-existent link between mother - newborn and the improvement of neurocomportamental performance ${ }^{1}$.

When the newborn is born, it is expected to perform basic functions like breathing, swallowing and sucking independently. However, considering that swallowing is ripe around the 11th week of gestation, the suction around the 32nd and the suction coordination, breathing and swallowing around the 34th week of pregnancy, many of these infants are born weeks before that development and need a long time until these functions are ripe, coordinates and can feed themselves safely ${ }^{2,3}$.

The establishment of breastfeeding in low weight newborn or premature newborns has particular difficulties for both, the mother and her child ${ }^{2}$. Due to stress factors these mothers have been through and the barrier and specificity in breastfeed as small newborn, it is necessary that these mothers are 
guided and assisted effectively during the first womb deals, correcting faults issues and emphasizing and praising what the mother is doing correct. Thus, the observation and evaluation of the first supply of the womb in a Neonatal Intensive Care Unit (NICU) become indispensable for such issues are seen early and, when necessary, daily interventions are made $^{4}$.

The duration of breastfeeding may be favored or restricted by biological, cultural, relating to health care and socio-economic. Health professionals, through their attitudes and practices, can positively or negatively influence breastfeeding initiation and duration ${ }^{5}$.

The importance of breastfeeding for preterm infants has been studied by many health professionals such as doctors, nutritionists and dentists. The existence of protocols to assess consumption of mother's womb, specific for preterm infants is still limited. Nowadays we observe the use, in most studies 5,6 of assessing breastfeeding protocol for full-term infants, designed by the World Health Organization (WHO), with the United Nations Children's Fund (UNICEF) ${ }^{7}$. This instrument was adapted by a speech therapist, validated for Speech Therapy Evaluation Form Feedings ${ }^{8}$, which takes into account aspects of breastfeeding based on the literature, personal experience and suggestions obtained in consulting specialists. The instrument consists of seven items, namely: I. aspects related to breast (anatomy, ejection signals, engorgement, trauma and pain); II. baby's oral reflexes (rooting, sucking, vomiting, bite, swallowing); III. mother/ newborn bond signs; IV. position mother/newborn during breastfeeding; $V$. ability to handle the breast; VI. milking conditions of the breast; and VII. final classification of the feed.

From the need to focus on specific points for the assessment of preterm infants at the time of feeding, Melo (2008) ${ }^{2}$ adapted the Speech Therapy Evaluation Form Feedings, observing the proper physiological condition of prematurity. Aspects deleted the adapted version were: vomiting reflexes, bite, sucking and swallowing, newborn arm position, mouth height and movement of the tongue.

Taking into account the data found in the literature and the daily observation of the need to evaluate mother-premature dyad at the time when the supply of mother's womb starts, the aim of this study was to evaluate premature infants during the first offering of the womb in a NICU.

\section{METHODS}

The study followed the observational crossmodel. It was approved by the Research Ethics
Committee of the Irmandade Santa Casa de Misericordia de Porto Alegre under number 434.378

Fifteen dyads mother- newborn were evaluated during the first offering of the womb in the Neonatal Intensive Care Unit in Maternity Mario Totta in the Hospital Santa Clara da Irmandade Santa Casa de Misericórdia de Porto Alegre.

The inclusion criteria used in the study were: gestational age (GA) according to the Capurro method between 20 and 37 weeks gestation and medical clearance to initiate breastfeeding. The presence of evil craniofacial formation, severe neonatal asphyxia, HIV-positive mother or other factors that prevented breastfeeding and the negative mother to participate were used as exclusion criteria.

Data were collected between the months of November 2013 and January 2014. With each dyad, this collection was divided in three parts, two before the first offer of the womb and the last during the observation of breastfeeding:

$1^{\text {st }}$ part) Consultation with the medical records of premature infants with completing a closed form with the following data: reason for hospitalization in the ICU, GA at birth (GAb) and Gestational Age corrected (GAc) birth weight and current weight, intrauterine growth curve, Apgar at 1 and 5 minutes, need for intubation, extubation failures and current feeding and speech therapy prior to initiation of breastfeeding, with oral motor sensory stimulation and / or oral stimulation with small amounts of breast milk or infant formula.

$2^{\text {nd }}$ part) Application to the mothers of a questionnaire with closed questions, developed by the authors: maternal age, education, marital status, good relationship or not with the newborn's father, type of delivery, previous pregnancies, abortion occurrence, conducting prenatal during the pregnancy, guidance on breastfeeding in the prenatal, previous experience in breastfeeding and duration of it, feel or not ready to start breastfeeding, fear or not to hold or breastfeed the newborn feel or not supported by the family and the health team assisting the newborn.

$3^{\text {rd }}$ part) Evaluation of the first offer of the womb through the application of the Speech Therapy Evaluation Form Feedings adapted ${ }^{2,8}$. In this form the maximum mark is two (2) points indicating observed suitable conditions, that is the closest to the ideal; one (1) indicates intermediate point conditions and zero (0) indicates improper conditions. The protocol consists of seven items assessing:

\section{I - Aspects related to mother's breast:}

a) Anatomy: protruding (2); semi-protruding (1); pseudo-protruding (0). 
b) Ejection signals: has two or more signals (2); only a sign (1); No sign (0).

c) Engorgement: absent (2); started (1); set (0).

d) Trauma and pain: absent (2); pilling (1); breast cracking or trauma (0);

II - Presence of the rooting reflex in newborn:

a) Rooting: Active (2); exacerbated active or not (0);

III - Mother / newborn bond signs:

- Newborn

a) Signs of autonomy: autonomous (2); little autonomous (1); dependent (0).

b) State of consciousness: alert or semi alert (2); drowsiness or light sleep (1); alarming cry or deep sleep (0).

- Mother

a) Mode to hold the newborn: firm, confident safe (2); holding the newborn a little loose (1); safe too loose, no confidence (0).

b) Attention to the newborn's face: eye contact (2); little eye contact (1); lack of eye contact (0).

c) Mother's physical touches on newborn: Frequently mother's touches (2); sporadic touches (1); absence of touches (0).

\section{IV - Position mother / newborn during breastfeeding:}

- As the mother

a) Comfort: Comfortable (2); discomfort (1); totally uncomfortable (0).

b) Mode of holding the breast: thumb up four fingers below (2); other positions to hold (1); without holding the breast (0).

c) The distance between hand and areola: safe away from the areola (2); safe near the areola (1); secured on the areola (0).

d) Pressure of the fingers in the milk ducts: moderate (2); excessive (0).

- Newborn Body / mother

e) Newborn Position: facing to the mother (2); facing side (0).

f) Distance: newborn near to the mother's body (2); newborn distant to the mother's body (0).

g) Head / neck: supported and free (2); little support (1); without support (loose) or too bent (0).

h) Newborn's Nose: free breathing (2); little occluded (1); completely blocked (0).

\section{V - Conditions of the newborn's hold on the breast;}
a) Newborn's chin: touches the breast (2); does not touch (0).
b) Mouth: wide open (2); little open (0).

c) Sealing lip: both fully turned outwards facing outwards or less (2); lower lip slightly facing outward (1); fully retracted lips (0).

d) Snapping the areola: the entire areola (2); little of the areola (1); only the nipple (0).

\section{VI - Milking conditions of the newborn on the} breast:

a) Jaw movement: coordinated (2); uncoordinated movements or chewing the nipple (0).

b) Cheeks rounded (without dimples) (2); tense or sucked (dimpled) (0).

c) Sucking rhythm: quick start after stable (2); only fast pace or just slow (1); absence of an established rhythm, unstable (0).

d) Standard suck / swallowing / breathing: coordinated (2); little uncoordinated (1); completely mismatched (0).

\section{VII - Final classification of the feed:}

a) Mother's mode to remove the newborn from the breast: expects the newborn drops spontaneously and / or offers other breast if the newborn wants (2); expects little time or offers other breast and removes soon (1); removes very fast (0).

b) Breast condition: emptied (2); little bit full (1); still engorged or too full (0).

c) Nipples condition: normal, pain-free (2); small skinning, little sore (1); sharp trauma, a lot of pain (0).

d) Newborn behavior at the end of the feed: Content, sleeps after feeding (2); light sleep or sleeps little and wake up soon (1); dissatisfied, restless, crying (0).

Data were organized in the 2013 Excel version of the program and were then statistically analyzed in SPSS version 19. The absolute frequency was calculated for qualitative variables and for the quantitative, minimum value and the maximum value found in the sample, the mean and standard deviation. To analyze the correlation between data from medical records, the responses of questionnaires to mothers and breastfeeding assessment was used the Spearman correlation test, considering significant results $p<0.05$.

\section{RESULTS}

\section{Sample characterization}

Of the 15 participants premature, 8 (53.3\%) were female, with a mean age of 24.93 days (SD \pm 18.05 ); the youngest 2 and older with 62 days of life. GAb (Capurro method) was between 28 and 36 weeks with 32 weeks mean (SD +/- 02,24). Birth 
weight ranged between 770 and 2320 grams, with an average of 1517.67 grams (SD +/- 473.72).

The reasons that led to the hospitalization of newborn in NICU are shown in Figure 1. All were premature and $7(46.7 \%)$ presented this as the sole reason for ICU admission. The other participants presented other (s) comorbidity (s) associated.

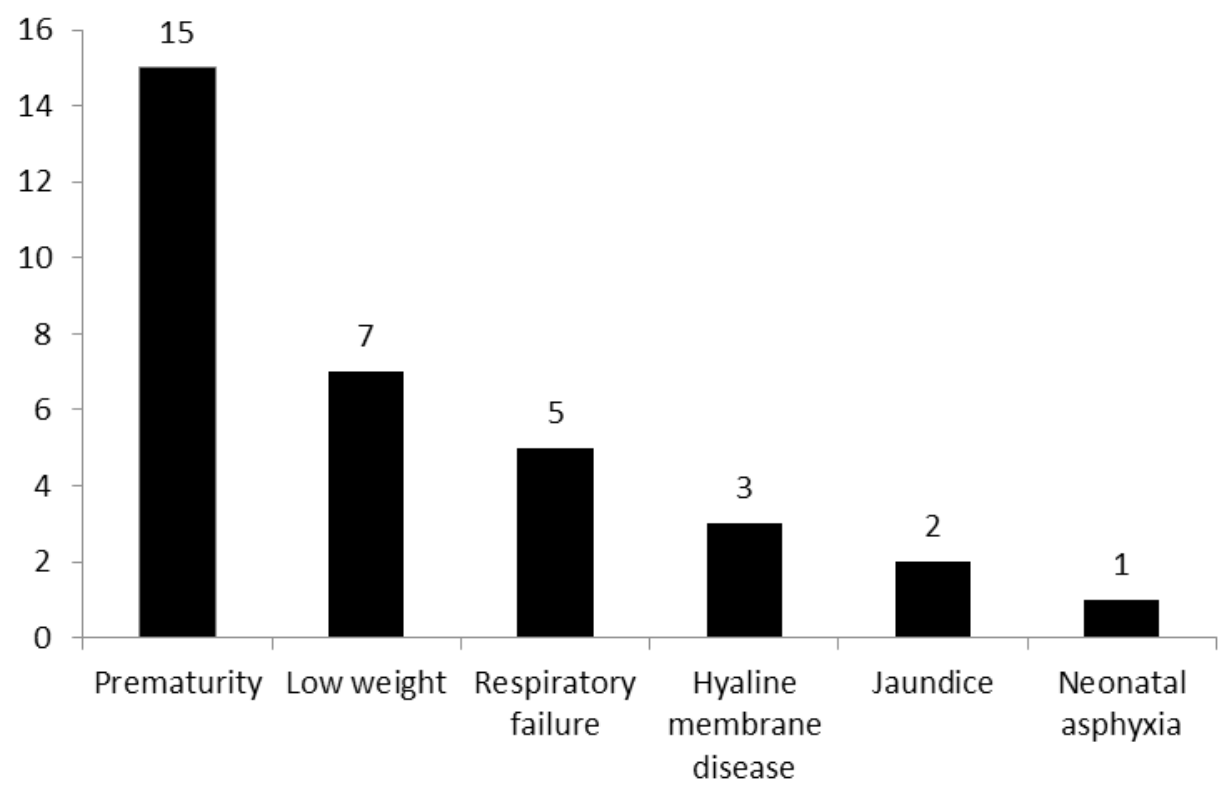

Figure 1 - Distribution of reasons for hospitalization of infants in the neonatal ICU

At birth 11 newborns (73.3\%) had intrauterine growth rated as appropriate for gestational age. Of the total, $7(46.7 \%)$ had Apgar 9 at 1 minute of life and $8(53.3 \%)$ in the 5 th minute of life. Six $(40 \%)$ required intubation and none had extubation failure.

On the day of the breastfeeding assessment, the GAc ranged from $33 \pm 5$ to 40 weeks, averaging 36 +3 weeks (SD +/- 01,57); and the weight between 1335 and 2205 grams, average of 1847.33 grams (SD +/- 236.66). The feed was orally (cup) + an alternative pathway (probe) in $8(53.3 \%)$ newborns. Nine prematures $(60 \%)$ were already in speech therapy when they started breastfeeding.

\section{Of the mothers}

The average age of mothers participants was 29.27 years (SD +/- 8,058); the youngest 17 and the oldest 41 years.

As for education, 6 (40\%) had incomplete grade 1 and 5 (33.3\%) had high school degree.

When asked about marital status, 6 (40\%) reported having stable relationship, $5(33.3 \%)$ are married and $4(26.7 \%)$ single. Of these, half (2) claimed to have a good relationship with the father of the newborn.
Of births and parities, $13(86.7 \%)$ were cesarean. $7(46.7 \%)$ were primiparous and $7(46.7 \%)$ had more than two children. Of the total sample, 2 (20\%) have had occurrence of abortion.

The number of pre-natal consultations was five or more for $10(66.7 \%)$ mothers. Nine $(60 \%)$ had not received guidance about breastfeeding in the consultations.

Of the mothers interviewed, 8 (53.3\%) had previous experience in breastfeeding, and 5 of these (33.3\%) breastfed for more than six months.

To start breastfeeding with premature, 11 (73.3\%) mothers said they were prepared; however, $8(53.3 \%)$ reported being afraid to hold her baby.

As for the support network at this time, 13 $(86.7 \%)$ mothers said they felt supported by their family, and 14 (93.3\%) said they felt supported by the health team that cared the child.

By comparing data from medical records, interview and assessment of breastfeeding, it was observed that the variable days of life showed a statistically significant result with strong correlation with the conditions of the handle of the newborn to the breast $(p=0.040)$. The more days of life, the better conditions for the handle of the newborn on breast. The GAc showed statistically significant 
results with strong correlation with the conditions of the handle of the newborn to the breast $(p=0.008)$, the newborn's milking conditions to the breast $(p=$ 0.012 ) and the final classification of breastfeeding ( $p$
$=0.037)$. That is, the higher the GAc, the better the conditions of the handle and milking the newborn to the breast and the final classification of feeding (Table 1).

Table 1 - Comparison between the items of Speech Therapy Evaluation Form Feedings adapted and data from medical records Newborn and questionnaire to mothers

\begin{tabular}{lllllllll}
\hline RATED ITEM & & I & II & III & IV & V & VI & VII \\
\hline \multirow{2}{*}{ Days of life } & CC & 0,3 &, 148 &, 317 &, 113 &, $535^{*}$ &, 285 &, 265 \\
& $\mathrm{p}$ & 0,28 &, 600 &, 250 &, 688 &, $\mathbf{0 4 0}$ &, 303 &, 340 \\
\multirow{2}{*}{$\mathrm{GA}$} & $\mathrm{CC}$ &,- 111 &, 099 &,- 037 &, 123 &,- 194 &, 052 &, 115 \\
& $\mathrm{p}$ &, 694 &, 725 &, 896 &, 663 &, 490 &, 853 &, 684 \\
\multirow{2}{*}{ GAC } & $\mathrm{CC}$ &, 235 &, 508 &, 257 &, 172 &, $656^{* *}$ &, $628^{*}$ &, $541^{*}$ \\
& $\mathrm{p}$ &, 398 &, 053 &, 355 &, 540 & $\mathbf{0 0 8}$ & $\mathbf{0 1 2}$ & $\mathbf{0 3 7}$ \\
\hline
\end{tabular}

$\mathrm{CC}=$ Correlation Coefficient

$\mathrm{GA}=$ Gestacional Age

$\mathrm{GAc}=$ Gestational Age Corrected

I - Related aspects of mothers breast

II- Presence of the rooting reflex in newborn

III- Mother / newborn bond signs:

IV- Position mother / newborn during breastfeeding

$V$ - Conditions of the newborn's hold on the breast

VI- Milking conditions of the newborn on the breast

VII- Final classification of the feed

Statistical test: Spearman's correlation coefficient $p<0,05$.

\section{DISCUSSION}

Breastfeeding depends on factors related to the mother (maternal age, desire to breastfeed, education, socioeconomic status etc.) as the newborn (birth conditions, prematurity, complications $)^{9,10}$. One study said that the perception about breastfeeding varies from mother to mother and some breastfeeding because they feel well and others because brings benefits to the newborn. Still, some incorporate the medical discourse about all the benefits that breastfeeding brings ${ }^{11}$.

\section{Factors in favor of breastfeeding}

\section{Maternal age}

As for maternal age, the average found in this study was 29,27 years old. This result is in line with other studies in which the authors concluded that the fact that the mothers had higher age was identified as a protective factor to breastfeeding in prematures $^{12,13}$.

\section{Maternal education}

Mother of the sample, $6(40 \%)$ reported the incomplete grade 1, 5 (33\%) high school complete, $2(13.3 \%)$ 1st school graduate, $1(6.7 \%)$ college complete and $1(6.7 \%)$ college incomplete. Although in this study the low education have not interfered at the beginning of breastfeeding, studies claim that the level of education directly affects the living conditions and health of people and understanding the instructions received. That is, the lower the education degree the higher the negative interference in breastfeeding ${ }^{6,10,14}$.

Maternal marital status and family support and health professionals

Regarding marital status, the majority of the sample $(40 \%)$ claimed to have a stable relationship. According to a study, this result is positive, because the support of the partner is extremely important to share the difficulties and responsibilities related to the birth of premature ${ }^{10}$. In addition, $86.7 \%$ of mothers said they felt supported by the family at this time and $93.3 \%$ of the sample said they felt that support also from the health team that assisted their newborns. Study says mothers to maintain lactation during the period that their newborn cannot be breastfed is important that they feel they are safe and have guidance and support from family and health professionals ${ }^{4}$. Other studies have found that mothers feel the need for health professionals to arrest not only the technical aspects of breastfeeding, but should also be open to dialogue with 
these mothers and be attentive to the uniqueness that each mother- newborn dyad presents ${ }^{15,16}$.

\section{Prenatal realization}

The Ministry of Health recommends the completion of at least six prenatal consultations, and preferably one in the first quarter, two in the second quarter and three in the third trimester of pregnancy ${ }^{17}$.

Strict monitoring during prenatal allows early identification and intervention in order to minimize damage to maternal and child health ${ }^{18}$. In the sample, $66.7 \%$ held six or more prenatal visits; however, $60 \%$ of the mothers received guidance on breastfeeding in the consultations. Studies claim that this guidance is essential to occur in the prenatal, since this measure is seen as capable of modifying the profile of breastfeeding in a population ${ }^{5}$. However, another study claims that this fact is changed when it comes to mothers of premature babies, since the initiation of breastfeeding is delayed; this guidance needs to occur more often and be taken up by health professionals involved in breastfeeding context, which end up gaining the trust of the mother ${ }^{19}$.

\section{Previous experience in breastfeeding}

When it comes to the previous experiences related to breastfeeding, $53.3 \%$ claimed to have breastfed other (s) son (s). A study says that mothers with previous positive experiences can be more successful in breastfeeding other children. However, this may not be enough stimuli to be considered when viewed individually, since several factors change in each pregnancy, including maternal age, family dynamics, socioeconomic conditions and problems with the newborn ${ }^{12}$.

\section{The initiation of breastfeeding}

Although this moment is of expectation and generates visible maternal anxiety, $73.3 \%$ of mothers said it was prepared to initiate breastfeeding. A study says that despite the stress factors involving this moment, the fact of seeing the newborn evolve and gain weight makes mothers feel well and prepared to face this new challenge ${ }^{20}$, this fact could also be observed on the mothers of the sample.

Newborn in the speech therapy accompaniment

In the sample of newborns, $9(60 \%)$ had speech therapy accompaniment before starting the supply of mother's breast. Due to prematurity, these infants have oral motor sensory changes in sucking reflexes, breathing and swallowing and interaction between them. To improve these aspects, and help mothers to feel calm and secure in contact and breastfeed their child act, speech therapy practice in neonatal
NICU is of great importance ${ }^{21}$. One study showed that oral motor stimulation and non-nutritive sucking improved readiness for oral feeding and efficiency of the same in premature newborns ${ }^{22}$.

\section{Factors that interfered in the breastfeeding}

In the sample, the mean gestational age at birth was 32 weeks and the approximate weight 1520 grams; these results were to meet another study of premature infants ${ }^{2}$. Prematurity was the main reason for hospitalization of newborns, and is one of the main risk factors for mortality and morbidity, the general immaturity can lead to dysfunction in any organ or body system and the complications in this period may represent long hospital stay and compromise the initiation of breastfeeding ${ }^{10,23,24}$.

Despite the speech therapy have started early in most of the sample, oral motor sensory stimulation and oral stimulation in the cup, with breast milk or infant formula, breastfeeding was initiated only under medical release, when the sample had GAc of average $36+3$ weeks.

The literature considers that the coordination of sucking $x$ breath $x$ swallowing (SxBxS) occurs around the 34th week of pregnancy, so it is important that breastfeeding and oral feeding start up from that period ${ }^{2}$. In the sample, only two newborns started breastfeeding and oral feeding before the aforesaid period because of the medical release. One of them was feeding alternative pathway + oral feed (cup) and the other only orally. A study said that up to 34 weeks of GAc should be only carried nonnutritive sucking stimulation due to the difficulty

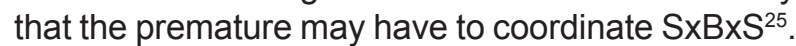
Another study stated that such coordination can already occur at 32 weeks, and that they take into account the clinical condition of the newborn ${ }^{26}$.

It is important to consider that only four newborns had GAc above 37 weeks, when considering newborn term, and it is during this period that these infants can coordinate SxBxS as well as those newborn term. A study said the GAc interferes directly in the nutritive sucking, or even unable to coordinate SxBxS at 34 weeks, the higher the GAc, the better the SxBxS coordination ${ }^{27}$. In addition, infants with GAc below 37 weeks may have difficulty in achieving proper latch breastfed, and perform milking and remain alert during the offer. Therefore it is common the rapid withdrawal of newborn of the breast, and even maternal withdrawal during the first offer ${ }^{2}$.

\section{CONCLUSION}

The higher the GAc and the more days of life premature have, the better the conditions handle 
the breast. In addition, the GAc is associated with milking conditions and the final classification of the feed.

Prematurity was the main obstacle to breastfeeding, however, the positive characteristics of mothers, such as educational level, marital status, previous experience in breastfeeding, and speech therapy started before breastfeeding in most newborns, may have provided good results in the first offering of the breast.

Due to the issues related to prematurity, such newborns must be accompanied by a multidisciplinary team, in order to stimulate immature functions. It is important to develop further studies with larger number of mother-premature dyads initiating breastfeeding.

\section{RESUMO}

Objetivo: avaliar recém-nascidos prematuros durante a primeira oferta de seio materno em uma Unidade de Terapia Intensiva neonatal. Métodos: foram avaliadas 15 díades mãe/recém-nascido durante a primeira oferta de seio materno na Unidade de Terapia Intensiva neonatal da Maternidade Mario Totta, no Hospital Santa Clara da Irmandade da Santa Casa de Misericórdia de Porto Alegre. A coleta ocorreu em três partes: $1^{\mathrm{a}}$ ) Consulta ao prontuário do recém-nascido e preenchimento de um formulário. $2^{\mathrm{a}}$ ) Aplicação de um questionário estruturado às mães. $3^{\mathrm{a}}$ ) Avaliação da primeira oferta de seio materno aplicando o Formulário de Avaliação Fonoaudiológica das mamadas. Resultados: $46,7 \%$ dos recém-nascidos apresentaram a prematuridade como único motivo de internação, $60 \%$ já estavam em acompanhamento fonoaudiológico antes de iniciarem o aleitamento materno. A média de idade das mães foi $29,27+/-8,058$ anos e $40 \%$ delas afirmou terem relacionamento estável com o pai do recém-nascido. Foi verificado que quanto maior a idade gestacional corrigida do recém-nascido, melhor as condições de pega e ordenha ao seio materno e classificação final da mamada, assim como, quanto mais dias de vida o recém-nascido tem, melhor a pega ao seio materno. Conclusão: a prematuridade foi o principal obstáculo para o aleitamento materno, porém, as características positivas das mães, como grau de escolaridade, estado civil, experiência prévia em aleitamento materno, e atendimento fonoaudiológico iniciado antes do aleitamento materno em grande parte dos RN, podem ter proporcionado bons resultados na primeira oferta de seio materno.

DESCRITORES: Aleitamento Materno; Prematuro; Unidades de Terapia Intensiva Neonatal

\section{REFERENCES}

1. Nascimento MBR, Issler H. Breastfeeding: making the difference in the development, health and nutrition of term and preterm newborns. Rev Hosp Clin Fac Med Sao Paulo [periódico na internet]. 2003 [acesso em: 12-01-2013] ; 58 (1). Disponível em: http://www.scielo.br/pdf/rhc/v58n1/15505.pdf

2. Melo AM. Avaliação da mamada em recémnascidos prematuros [dissertação]. Recife (PE): Universidade Federal de Pernambuco, Centro de Ciências da Saúde; 2008.

3. Arvedson J, Clark H, Lazarus C, Schooling T, Frymark T. Evidence-based systematic review: effects of oral motor interventions on feeding and swallowing in preterm infants. American Journal of Speech Langage Pathology. 2010;19(4):321-40.

4. Serra SOA, Scochi CGS. Dificuldades maternas no processo de aleitamento materno de prematuros em uma UTI Neonatal. Rev Lat Am Enfermagem [periódico na internet]. 2004 [acesso em: 12-012013]; 12(4):597-605. Disponível em: http://www. scielo.br/pdf/rlae/v12n4/v12n4a04.pdf

5. Carvalhaes $\mathrm{MBL}$, Corrêa $\mathrm{CRH}$. Identification of difficulties at the beginning of breastfeeding by means of protocol application. $J$ Pediatr. [periódico na internet] . 2003 [acesso em: 15-012013];79(1):13-20. Disponível em: http://www. scielo.br/pdf/jped/v79n1/v79n1a05.pdf

6. Scheeren B, Mengue APM, Devincenzi BS, Barbosa LR, Gomes E. Condições iniciais no aleitamento materno de recém-nascidos prematuros. J Soc Bras Fonoaudiol. [periódico na internet] 2012 [acesso em: 15-01-2013]; 24 (3). Disponível em: http://www.scielo.br/pdf/jsbf/v24n3/ v24n3a03.pdf 
7. UNICEF. Breastfeeding management and promotion in a baby-friendly hospital: an 18-hour course for maternity staff. 1993.

8. Sanches MTC. Dificuldades iniciais na amamentação: enfoque fonoaudiológico. [dissertação]. São Paulo (SP): Universidade de São Paulo; 2000.

9. Silva RV, Silva IA. A vivência de mães de recémnascidos prematuros no processo de lactação e amamentação. Esc Anna Nery Rev Enferm. [periódico na internet]. 2009 [acesso em: 25-012013];12(1):108-15. Disponível em: http://www. scielo.br/pdf/ean/v13n1/v13n1a15.pdf

10. Cuman RKN, Ramos HAC. Fatores de risco para prematuridade: pesquisa documental. Esc Anna Nery Rev Enfm. 2009;13(2):297-304.

11. Marques DM, Pereira AL. Amamentar: Sempre benefícios, nem sempre prazer. Cienc Cuid Saude [periódico na internet]. 2010 [acesso em: 25-012013];9(2):214-9. Disponível em: http://periodicos. uem.br/ojs/index.php/CiencCuidSaude/article/ download/8963/6069.

12. Beck AMO, Assunção KO, Barbosa LR, Gomes E. Influência do ambiente hospitalar nos aspectos relacionados ao aleitamento materno. Rev Soc Bras Fonoaudiol. [periódico na internet]. 2012 [acesso em: 25-01-2013];17(4):464-8. Disponível em: http:// www.scielo.br/pdf/rsbf/v17n4/17.pdf

13. Merewood A, Brooks D, Bauchner $\mathrm{H}$, MacAuley L, Mehta SD. Maternal birthplace and breastfeeding initiation among term and preterm infants: a statewide assessment for Massachusetts. Pediatrics. [periódico na internet]. 2006 [acesso em: 25-01-2013];118(4):1048-54. Disponível em: http:// www.ncbi.nlm.nih.gov/pubmed/17015498

14. Czechowski AE,Fujinaga $\mathrm{Cl}$. Seguimento ambulatorial de um grupo de prematuros e a prevalência do aleitamento na alta hospitalar e ao sexto mês de vida: contribuições da Fonoaudiologia. Rev Soc Bras Fonoaudiol. [periódico na internet]. 2010 [acesso em: 02-02-2013];15(4):572-7. Disponível em: http://www.scielo.br/pdf/rsbf/v15n4/ a16v15n4.pdf

15. Souza SNDH, Mello DF, Ayres JRCM.O aleitamento materno na perspectiva da vulnerabilidade programática e do cuidado. Cad Saude Publica. [periódico na internet]. 2013 [acesso em: 02-02-2013]; 29(6):1186-94. Disponível em: http://www.scielo.br/pdf/csp/v29n6/a15v29n6.pdf

16. Araújo BBM, Rodrigues BMRD. Vivências e perspectivas maternas na internação do filho prematuro em Unidade de Tratamento Intensivo Neonatal. Rev Esc Enferm USP. [periódico na internet]. 2010 [acesso em: 02-022013];44(4):865-72. Disponível em: http://www. scielo.br/pdf/reeusp/v44n4/02.pdf
17. Manual Técnico Pré-natal e puerpério. Atenção qualificada e humanizada. Brasília, DF; Ministério da Saúde. 2006. Disponível em: http://bvsms. saude.gov.br/bvs/publicacoes/manual_pre_natal_ puerperio_3ed.pdf

18. Nascimento RM, Leite AJM, Almeida NMGS, Almeida PC, Silva CF. Determinantes da mortalidade neonatal: estudo caso-controle em Fortaleza, Ceará, Brasil. Cad Saude Publica. [periódico na internet]. 2012 [acesso em: 10-012014]; 28(3):559-72. Disponível em: http://www. scielo.br/pdf/csp/v28n3/16.pdf

19. Braga PP, Almeida CS, Leopoldino IV. Percepção materna do aleitamento no contexto da prematuridade. Rev. Enferm. Cent.-Oeste Min. [periódico na internet]. 2012 [acesso em: 02-022013];2(2):151-8. Disponível em: http://www.seer. ufsj.edu.br/index.php/recom/article/view/177/298

20. Souza NL, Pinheiro-Fernandes AC, ClaraCosta ÍC, Cruz-Enders B; Carvalho JBL; Silva MLC. Domestic maternal experience with preterm newborn children. Rev Salud Publica (Bogota). [periódico na internet]. 2010 [acesso em: 02-022013]; 12 (3): 356-67. Disponível em: http://www. ncbi.nlm.nih.gov/pubmed/21311824

21. Pinheiro JVL, Oliveira NM, Júnior HVM. Procedimentos fonoaudiológicos em recémnascidos de alto risco. Rev. bras. promoç. Saúde [periódico na internet]. 2010 [acesso em: 02-022013]; 23(2):175-80. Disponível em: http://www. unifor.br/images/pdfs/rbps/artigo10_2010.2.pdf

22. Calado DFB, Souza R. Intervenção fonoaudiológica em recém-nascido pré-termo: estimulação oromotora e sucção não-nutritiva. Rev CEFAC. [periódico na internet]. 2012 [acesso em: 02-02-2013];14(1):176-81. Disponível em: http:// www.scielo.br/pdf/rcefac/v14n1/194-09.pdf

23. Martins EL, Padoin SMM, Rodrigues AP, Zuge SS, Paula CC, Trojahn TC et al. Caracterização de recém-nascidos de baixo peso internados em uma unidade de terapia intensiva neonatal. Rev. enferm. UFSM. [periódico na internet]. 2013 [acesso em: 02-02-2013]; 3(1):155-63. Disponível em: http:// cascavel.ufsm.br/revistas/ojs-2.2.2/index.php/ reufsm/article/view/7412/pdf

24. Basso CG, Neves ET, Silveira A. Associação entre realização de pré-natal e morbidade neonatal. Texto Contexto Enferm. [periódico na internet]. 2012 [acesso em: 02-02-2013]; 21 (2). Disponível em: http://www.scielo.br/pdf/tce/v21n2/a03v21n2.pdf

25. Medeiros AMC, Oliveira ARM, Fernandes AM, Guardachoni GAS, Aquino JPSP, Rubinick ML et al. Caracterização da técnica de transição da alimentação por sonda enteral para seio materno em recém-nascidos prematuros. J Soc Bras Fonoaudiol. [periódico na internet]. 2011 [acesso 
em: 05-02-2013];23(1):57-65. Disponível em: http:// www.scielo.br/pdf/jsbf/v23n1/v23n1a13.pdf

26. Yamamoto RCC, Bauer MA, Häeffner LSBi, Weinmann ARMI, Keske-Soares M. Os efeitos da estimulação sensório motora oral na sucção nutritiva na mamadeira de recém-nascidos pré-termo. Rev CEFAC. [periódico na internet]. 2009 [acesso em: 05-02-2013];12(2). Disponível em: http://www. scielo.br/pdf/rcefac/v12n2/117-08.pdf
27. Yamamoto RCC, Keske-Soares M, Weinmann ARM. Características da sucção nutritiva na liberação da via oral em recém-nascidos pré-termo de diferentes idades gestacionais. Rev Soc Bras Fonoaudiol. [periódico na internet]. 2009 [acesso em: 10-02-2013];14(1):98-105. Disponível em: http://www.scielo.br/pdf/rsbf/v14n1/16.pdf

Received on: April 23, 2014

Accepted on: November 25, 2014

Mailing address:

Patrícia Keitel da Silva

Rua São Mateus- 742

Porto Alegre, RS - Brasil

CEP: 91410-030

E-mail: patikeitel@gmail.com 